\title{
Identity and Communication Pattern of Berco Tribe in Sumbawa Regency concerning Land Conflict Situation
}

\author{
M Syukron Anshori ${ }^{1, a)}$ Aka Kurnia SF ${ }^{2)}$ \\ ${ }^{1}$ Universitas Teknologi Sumbawa, Sumbawa, Indonesia \\ a)author correspondence : syukron.anshori@uts.ac.id \\ ${ }^{2}$ Universitas Teknologi Sumbawa, Sumbawa, Indonesia
}

DOI: https://doi.org/10.18196/jkm.121037

Article Info

Article history: Received 12 Mar 2020

Revised 4 Apr 2020

Accepted 5 May 2020

\section{ABSTRACT}

This research aims to analyze the communication process of the Berco tribe in Sumbawa Besar that figured in establishing their reality in agrarian conflict. This study is distinctive and novel since the social science approach, including the pattern of communication, symbol, culture, and identity, was used as the approach. This research used a qualitative study with an over-participants approach, and the informants of the study were chosen using goodness criteria with a purposive sampling technique. In analyzing the data, the author used a model of interactive technique by Miles and Huberman that comprised three steps: data collection, data reduction, data display, and conclusion. The results showed that the Berco tribe held their cultural tradition solidly as a way to show their existence during the conflict. Rapulung, or deliberate instruction communication patterns, became a process that is imposed during the conflict. Furthermore, the use of native language, namely 'Berco,' is one of the cultural identities that is considered important as a form of resistance and becomes the individual variability in influencing the choices and strategies in the conflict situations.

Keywords: Communication Patterns; Conflict Resolution; Cultural Identity; Indigenous People

\begin{abstract}
ABSTRAK
Penelitian ini bertujuan untuk melihat proses komunikasi yang dilakukan oleh masyarakat adat suku Berco di Kabupaten Sumbawa Besar dalam membangun realitas pada konflik urusan pertanahan yang dihadapinya. Penelitian ini dirasa penting karena menggunakan pendekatan ilmu social dalam konflik wilayah agraria sehingga dapat menjadi salah satu pendekatan baru pada kajian ilmu komunikasi terkait pola komunikasi, symbol, budaya dan identitas. Dengan menggunakan jenis penelitian kualitatif dan pendekatan overt-participants dan pemilihan informan berdasarkan goodness criteria yang ditentukan dengan teknik purposive sampling. Dalam menganalisis data penelitian, penulis menggunakan teknik model interaktif Miles dan Huberman (1984) melalui proses pengumpulan data, data reduksi, display dan kesimpulan. Hasil penelitian menunjukkan bahwa masyarakat suku Berco sangat kental dalam penggunaan budaya sebagai salahsatu cara memperlihatkan eksistensi diri ditengah konflik yang dihadapinya. Pola komunikasi deliberate instruction atau dalam konsep identitas masyarakat suku Berco disebut sebagai Rapulung menjadi proses yang diberlakukan pada saat menghadapi situasi konflik. Selain itu, penggunaan bahasa asli yaitu bahasa 'Berco' menjadi salah satu identitas kebudayaan yang dianggap penting sebagai bentuk perlawanan dan menjadi variabilitas individu dalam mempengaruhi pilihan dan strategi pada situasi konflik.
\end{abstract}

Kata Kunci: Identitas Budaya; Masyarakat Adat; Pola Komunikasi; Resolusi Konflik 


\section{INTRODUCTION}

Recent research concerning land conflict has been carried out by many academicians by focusing on non-litigation, juridical, and empirical law perspective. However, rarely did the research involve communication patterns. A study that considers communication patterns in the land conflict situation through communication study is rare, although, theoretically, in a conflict, interaction and conversation construct the reality held by the actor as a result of its experience and action (Denzin, 1989; Kriyantono, 2012).

Turner (1982) observed that individuals in a social group that shares a collective identity assume that they are members of the same social group. Against the definition, individuals in a social group often share collective perception to act as a group. Many academicians contend that, after that internal aspect arise, social identity that acts as a determiner in constructing perception and behavior follows (Greenaway et al., 2015). This understanding of identity can be useful to provide a general perspective in comprehending a particular relationship pattern. Communication that exhausts identity as the primary method is deemed influencing individual behavior towards society, primarily for a member of the group with a shared identity. It is not surprising if a member with a shared identity would be trusted, respected, and influential as opposed to those who do not (Spears \& Postmes, 2015; Ellemers, Spears, \& Doosje, 1999, Haslam, 2001 in Greenaway et al., 2015). Indeed, as claimed by Greenaway et al. (2015), the communication process within a collective identity may produce a complete and deep motivation for each individual.

Social identity perspective, which, according to Hogg and Reid (2006), has a cognitive and self-conceptual function, works in the dimension of social-group. This shows that interaction implicitly has a mindset, feeling, and behavior in a group so that what is uttered conveys information about the social norm. For Turner (1982), social behavior tends to display the variation of cognitive characteristic as the locus of control of the individual, which lead to group identity. In a social situation, social identity will augment the tendency of producing effects from individual behavior. In contrast, attitude, behavior, and beliefs are considered the result of adaption toward the social environment that is useful for constructing and interpreting an event and create perception and establish a reality eventually (Suzuki, 1997).

From the perspective of Bavelas (1950), that process stems from individual or group propensity towards a communication pattern that is exercised to satisfy ideas, diffuse information, and complete a decision-making process to yield interaction patterns from a particular social process. The relationship among this interaction process cannot be separated from knowledge and skills used to affect the quality and effects of each decision and action in the interaction process created (Hirokawa, 1980).

Jeong (2005) gave a view regarding interaction, which he believed starts from verbal message through conversation and message reply that is transmitted so that it would produce negotiated meaning and be reconstructed through the interaction process. For Jeong, a social interaction process takes place owing to meaningful behavior exchange (verbal/ non-verbal) to improve ones' relationship with others. For example, an information exchange for the sake of coacquainting (Liliweri, 2005). Quite Similar to Jeong (2005), Woo and Reeves (2007) opine that interaction and conversation are held due to interpretation that can happen anywhere and anytime. However, they also believe that the scope is wider than that until covering response, negotiation, inventing new ideas, and resolving a problem.

One of the primary sources of power of group communication, according to Festinger (1950), is a demand for uniformity of information that can demonstrate and forms the behavior pattern of each member through the communication process in either conceptual or operational level. This process should be performed via effective communication among members so that it can affect the quality and interpretation of meaning in the interaction process. Turner (1982) believed that in the social cohesion model, the structure of the group burgeons as a product of interaction and relationship that affects the members, although, in general, the social group is conceptualized from some individual that connects and interacts immediately, face-to-face, to affect each other.

Fisher (1986) divides interaction patterns into a visible and invisible relationship. For Fisher, communicative behavior is needed to be applied and related to knowledge on the relation of internalfilter conceptual variables. However, in communication science, this pattern is only utilized as a theoretical assumption that cannot explain variable that is internal to the self of an individual, which is expressed in Fisher's vocabulary (1986), inherent inferential blackhole. 
Hinds dan Mortensen (2005) recommended a spontaneous communication pattern that can assist in developing a common identity. Apart from not having an immediate effect, spontaneous communication can be a pattern of interaction to facilitate and resolve conflict. This process depends on the action of each team member that converse the input through the cognitive and verbal process and behavior that is directed to achieve a common goal. Turner (1982) firmly believed that members in the social group identify themselves through interaction with each other, which is a development of the social structure. Differences among social cohesion concepts using social identification are based on psychologically determined explanation through an approval group membership.

Social cohesion model a la Turner (1982) stated that a member of a group has affection bounding that implies that an individual is tied to a common group. Furthermore, Bavelas (1950) saw the urgency of communication perspective as a part of the process of relation analysis and human interaction that relies on the efficacy of communication and can affect the success of a relationship. Sarbaugh, Thompson, and Feldman (1998, in Hinds and Mortensen, 2005, p. 291) asserted the importance of conversation as a part of an adequate mechanism to avoid various potential conflicts that often appear on interaction process.

Admittedly, it is true that from a communication perspective, commitment and belief are the main features of partnership forms and conflict resolution that tend to solve a common problem, and not for forming domination of the members (Mohr \& Spekman, 1994). However, interaction and collective identity will rule out emotion and personal opinion or limitation towards the creativity of group members (Owens, Robert, Valesky \& Thomas, 2007). An individual that is a part of a group shows a particular behavioral pattern to affect other members in starting an action (Turner, 1982). Festinger (1950) opined that it is difficult to equate attitude and opinion towards a social group that fits with individual wish. This discordance is often not inherent so that individuals that have similar perceptions and references inclined to share opinions with members that have a similar perception. As a result, an individual that disagree with other member tends to resign from the group and opt for creating another group. Each individual tends to discriminate between aspects to create a common perception, which is defined by Kriyantono (2012) as an interpretation process towards object or reality.

Based on Salim's and Abdullah's research (2012), it is shown that the root of a conflict is around unpaid compensation, worker problem, and intervention of the third party in the contract. As argued by Alting (2013), the root problem of conflict is respect towards the right of land and inappropriate compensation. Salim and Abdullah (2012) identified that at least there are five conflicts among people of the Sumbawa Regency (Hereafter Sumbawa) with PT. Newmont Nusa Tenggara that includes conflict of community development, land, destruction of the village head of Ropang village, and divestment of share, as well as the contract of work in the region of Elang Dodo forest.

On the one hand, Rachman and Siscawati (2014) viewed territory as a geographical line to keep other people not infiltrate the area and to give permission and forbid activities in the area of the geographical line. Consequently, a claim of land that is under the government's control is undebatable (Kurnia, 2007). Referring to Nanang's and Inoue's statement (2002) that many Southeast Asian countries own and control more than half of the forest. That is, forest management, development, and protection is centralized and based on the assumption that the government is en effective forest manager.

However, as a cultural entity, indigenous people create, take care of, and pass down culture from one generation to another until it becomes its institution. This statement is supported by $\mathrm{Li}$ (2001) that said that most Indonesian people believed that culture is a heritage that firmly roots in a region. The significance of understanding a culture is to understand what happens in society. This case is viewed by Kim (2001) as a social construction in establishing a particular knowledge. In fabricating that construction, interaction process, and social hints occur, primarily that is related to certain values and beliefs that make a possible exchange through the transmission of cultural elements (Suzuki, 1997).

In Lawin village, district of Ropang, Sumbawa, there is a group of people that are called as Cek Bocek Salesek Reen Sury or only Berco tribe. These people have lived since 1512 (Gunawan, 2015; Anindita, 2015; Anshori, 2017). Their social and cultural habit demonstrates the existence of the Berco tribe. Spradley (2016) said that culture is transmitted to a group of people through habit or way of life. Compared to Sumbawa's people in general, this group has a different primary and 
everyday language, namely the Berco language. In Bakhtin's dialogical theory (Jeong, 2005), language can provide a theoretical framework to interpret and understand group interaction in the collaborative process. According to this theory, language is a part of the social context. It is interpreted multifariously, including in the conflict that can influence the meaning of the message.

Furthermore, Spradley (2016) conteded that language is not only capable of communication means of reality but also to create reality. Thus, different languages can make and express different experiences, and therefore language is considered to be the primary tool in transmitting culture from one generation to another. Thorkildsen and Ekman (2013) saw cultural heritage as not an object or usual site. Instead, they saw it as a process, and the outcome can transmit ideas extensively with people's contemporary needs. In other words, in the interaction process, conflict happens since there is a party that tries to oppose other parties with different views or acquire what they need so that a process of social interaction that forms as a conflict is accompanied by psychological and physical violence (Liliweri, 2005).

Recent research tends to analyze the phenomenon of conflict of land in Indonesia through the perspective of legal-formal and social. These approaches can affect activity and communication on a particular group of people, primarily in a conflict of land. The introductory interview found that communication becomes a weak aspect of the Berco tribe in Sumbawa. Also, the concept of identity of the Berco tribe is transformed through cultural rituals that have been experienced by many generations.

\section{METHODS}

The research used descriptive and qualitative methods, and, furthermore, to acquire data needed, these data collection methods were chosen: the first is an in-depth interview, and this method was performed to obtain information concerning cultural identification and communication patter on Berco tribe in Sumbawa regency. The second is an overt-participant that was done to observe activities and individuals on the situation of conflict (Kriyantono, 2014). The informants were individuals in the structure of the Berco tribe and chosen purposively. The assumption of Guba, Smith, and Marshall (1990) was appropriated to meet goodness criteria, that said that research is the process of uncovering what people believe to be true (regardless of any absolute truth)" (p. 190). In other words, proper research can be an objective truth.

Another important point from Spradley (2016) is related to information identity. If the informant rejects to publish the identity, the researchers will conceal the identity. As Spradley (2016) said, the researchers keep and protect the identity of the informant for safety and convenience reason. This is because the research is related to conflict and, therefore, can threaten the existence of the informant. As academicians, the researchers is responsible not to abuse identity that has been shared. For analyzing research data, the researchers used the technique of interactive model from Miles and Huberman (1984) through data collection, data reduction, data display, and conclusion.

This research is based on a concept of 'going exploring' that involved an in-depth and caseoriented study of some cases or single (Finlay \& Ballinger, 2006). In other words, qualitative research was formed by using the informant's perspective based on his experience and way of living (Brørby, 2013). In real life, the concept of going exploring investigates and understands the phenomenon directly in reality as a holistic whole (Brørby, 2013; Kriyantono, 2015).

\section{RESULT AND DISCUSSION}

Brown, Yelsma, and Keller (1981) argued that conflict is initially caused by social relationship problems as a consequence of social life. It is crucial to analyze the background of a phenomenon to comprehend the pattern of interaction, which roots on social perspectives. Kim (2001) held that social construction is established based on reality, knowledge, and education. Besides, Kendon's social interactionism perspective uttered that personal identity and social structure are considered as the product of and result from the process of interaction.

Berco tribe is an indigenous community that holds specific values in communication as an essential aspect of culture which has applied from a long time ago. This communication is called deliberate instruction, which means a pattern of communication by delivering direct instruction from village elders (a chief or a council) to the members of society about the rules of behaving and acting. This can be seen from the result and process of decision making upheld and obeyed by the members 
of Berco Tribe. This type of community was perceived by Gadgil, Berkes, and Folke (1999) as a community that possesses inheritance knowledge and belief about culture and the relationship among living creatures to the environment. The researchers analyzed the established pattern from the similarity of identity and the behavior of every member of the tribe to comprehend Berco Tribe's communication pattern. Based on the similarity of that identity, a member of the community was more trustable, respectable, and influential, compared to an individual that was not.

DS explained that:

"Ia karena nanmo rua luk kesepakatan dalam desa darat kami terutama pang dalam masyarakat adat sendiri. Pasti tu ete keputusan ke mufakat nan rapulung singin nan".

(This has become the indigenous community's agreement in decision making consensually through the process of Rapulung).

(An interview with DS, February 4, 2019).

This process has become the customary law as has been explained by IS:

"Kam hukum adat kami dean.. Jadi nongka tupina-pina sarea na"

(That is our customary law that has been preserved from generation to generations, and it is not made up).

(Interview with IS, February 4, 2019).

The result of the research showed that a chieftain (Bengko) was the decision-maker. He decided through a process of rapulung (community's discussion), and indigenous community elders attended and witnessed, together with all community members. Every crucial decision concerning the members' right to live was decided by discussion in Bale' Adat (a tradition house) through a mechanism of Rapulung adat. This discussion mechanism cannot be exercised without the presence of chieftain and must be done in that traditional house. A chieftain and the village apparatus directly led this mechanism.

\section{The Existence and Reality of Berco Tribe in Lawin Village, Sumbawa Besar}

The result of the research showed that the reality of social groups in society could be proven by the existence of the similarity of identity and belief that are built collectively, especially in indigenous people that have lived and shared similar identity for a long time. Gunawan (2015) described that Berco Tribe has lived from 1512 to nowadays. According to that explanation, Li (2001) also believed that the indigenous people in Indonesia had existed far longer than the establishment of The Unitary State of the Republic of Indonesia. One of this research's subject, DS, explained that:

"Le mo ka ada masarakat ta, kaleng jaman sepuan ana kamo tu telas..bahkan senopoka ada negara ta kamo tu ada kami, tu telas pang ta.. dunung sepuan ana ka datang Dewa Datu Awan Mas Kuning..nan nya ka cerita mula. Ten 1512 kam ada kami ka”. (We as indigenous people have lived here for an extended period before the establishment of this country. Historically, it was initially the arrival of Dewa Datu Awan Mas Kuning. Since 1512, we have been living here). (Interview with DS, February 4, 2019).

That statement of DS confirmed the early assumption that Berco Tribe has been living hereditarily for a long time ago before the establishment of the Republic of Indonesia.

A traditional system organizes this indigenous group. Furthermore, the system of belief and traditions have been communicated from generation to generation. Administratively, Berco Tribe is located in Lawin Village and Lebangkar Village, Ropang Districts, Sumbawa Regency, which was led by the indigenous government leader, namely Datu Sukanda RHD as a chieftain. The interview with DS found that there was a situation where the territory of customary laws and the administrative territory of the village intersects. DS explained that:

"Ba serea tau desa ta noroa no ikut aturan adat, leng tau ta tama dalam wilayah adat kami.. mana si ada kepala desa apa tetap si dean". (All the people here must obey our customary laws, because the village locates in our customary territory, albeit here exists a chief of the village). (Interview with DS, February 4, 2019). 
Administratively, Berco Tribe is the citizens of Lawin Village and Lembangkar Village. Nevertheless, when they are confronted with the situation of culture, tradition, and society's rituals, they are a part of indigenous people, as stated by IS that:

"Pemerintah desa ke, guru ke, sai-sai detama kota, muntu ikutmo aturan adatta dadimo masyarakat adat, kapangantan ke tau nta dadi mo dean, nan anak adat singin". (Anyone who follows and obeys the customary laws, he/she is considered as indigenous people. If someone or whoever marries one of the members of indigenous people, he/she is called as indigenous children). (Interview with IS, February 4, 2019).

The statement of DS is strengthened by IS, SB, and AZ who said that anyone who comes into the customary territory, follows the customary rules, and marries one of the members of indigenous people, he/she automatically becomes the member of indigenous people named by the society of Berco Tribe as the indigenous children.

\section{Berco Language as a Unifying Identity}

The language of Cek Bocek Selesek Reen Sury, in addition to differing from other languages in Sumbawa Regency, figures in unifying. This language is named Berco Language and called a unifying language since it united the members of Berco Tribe that came from the same ancestor. Apart from traditional language, Berco Language was also used by the indigenous people outside the customary territory for communicating. In the interview, SB explained that it is highly demanding to imitate the Berco Language, implying that anyone who did not understand the Berco Language was not a member of Berco Tribe. SB said that:

"Nosi nene bau tero basa kami, sebab lin basa kami ta ke basa semawa. Jadi lamin ada tau ngaku-ngaku tau kita, ba tu tes ajak laong ke basa berco. Lamin nototegas berati siong tau kita." (Our traditional language differs from other Sumbawa's language, and it is too tough to be imitated. Therefore, if there is someone who admits as a member of indigenous people but he/she does not understand our traditional language, it can be concluded that he/she is not a part of the indigenous people of Ce Bocek). (Interview with SB, November 13, 2018).

Berco Language has high intonation and fast pronunciation. Generally, most Sumbawa people did not comprehend Berco Language, while the society of Cek Bocek can pronounce the Sumbawa Language easily. Hence, to communicate verbally with guests/visitors, Sumbawa Language or Indonesia Language was used. Berco Language, as a traditional language, owned an advantage in the context of conflict faced by society. The verbal terrors which were practiced by external parties will be too conveniently faced and ignored by using Berco Language in communication.

\section{Socio-Cultural Life and Traditional Ritual as a Form of Communication for the Berco Tribe}

Geographically, the society of Berco Tribe cannot be separated from the condition of sociocultural life, which also develops dynamically. As the era grows, the identity was still preserved through the high spirit of close-knit cooperation (gotong royong) among the societies, conducting rituals, traditions, and beliefs on the one identity. For example, the society conducted cooperation like building worship infrastructure, traditional houses, village meeting halls, home residents, and others, which had been patterned from generation to generation. 


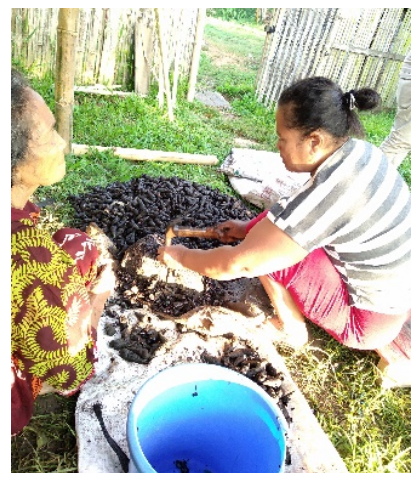

(a)

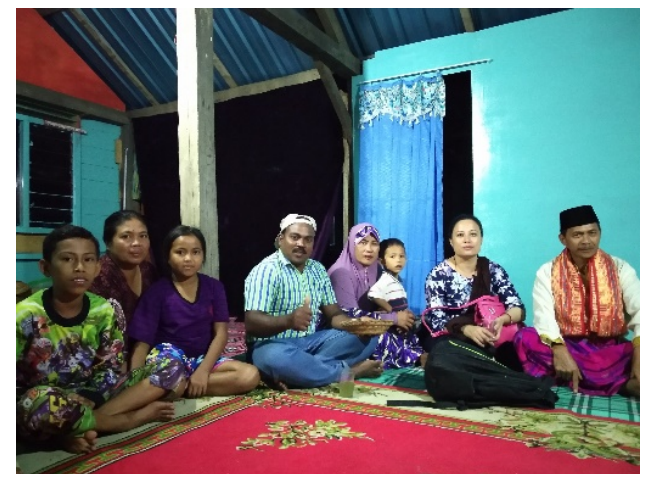

(b)

Figure 1. (a) Indigenous females of Berco Tribe are cooking traditional food, (b) a meeting between a chieftain and his relative (source: Personal Documentation)

In the context of cultural life, Berco Tribe possessed their own characteristic, particularly the songs that they were played differ from other languages in most of the Sumbawa Regency. For example, a song entitled "Berco" is an original song of the society of Berco Tribe composed by the previous indigenous generation. Besides, although the appearance of their traditional clothes is almost similar to other traditional clothes, the fundamental differentiator among their traditional clothes is when they performed in a significant cultural event.

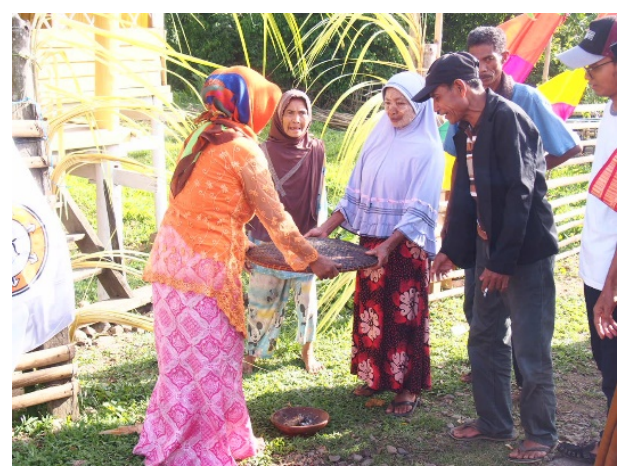

Figure 2. The traditional procession of welcoming guests/visitors (source: Personal Documentation)

In welcoming guests/visitors, the society of Berco Tribe was extremely heterogenic and appreciative; even they were more concerned with the guests who came from outside the customs territory. Afterward, in making customary decisions, a mechanism of Rapulung Adat is applied, which was led directly by the chieftain and other apparatuses of the indigenous government. Customary laws were highly durable and already ingrained.

The belief system of Berco Tribe is Islamic, which was initially preached by Dewa Datu Awan Mas Kuning in Kongkar Dodo. Their livelihood is farming, raising livestock, producing brown sugar (or they call as "Bajalid"), gardening coffee, collecting honey, and others. This society then established its own cultures and rituals based on the heritage of their ancestors. The unity of the society of Berco Tribe has been proven by the sustainability of doing traditional rituals from the leadership of Dewa Mas Kuning in 1512 to the leadership of Datu RHD. IS narrated that those cultures and rituals become routine agenda that are conducted every year. Whether the presence or not of a mining company, the indigenous people will continually preserve their cultural heritage. As stated by IS below:

"Sebenar ada ndak perusahaan ta, kami tetap tulestarikan adat istiadat. bahkan lemen ada acara rea-rea tetap ada persembahan kaleng komunitas adat. Ke ampo denongka putes dalam acara adat seperti sedekah zakat nan engka tubilin, ya ada apa ndak perusahaan tetap tuboat karena deta ka kaleng sapuan anamo". (We as an indigenous people will permanently preserve our cultures and rituals which have been practiced and inherited by our ancestors. Apart from the 
presence or not of a mining company, we will always stand on our rituals and cultures). (Interview with IS, November $13^{\text {th }} 2018$ ).

The research discovered that the rituals like jango kubir, eneng uran, nabar, main asu (hunting) and sedekah zakat became a medium of communication (silaturahmi) among the societies in order to be always connected to the ancestors. They used cultures as one of the ways to defend themselves from modernism, which had started to infiltrate the customary territory and a part of survival. DS told the differences before and after the presence of a mining company which is believed as a source of conflict, as below:

"Ada nda perusaaan nan kami ta tetap si tu ada, apa jina tu pikir nya apa. Tetap ke budaya tradisi kami. Lamin senopoka tama perusaan nan kami tu telas nyaman.. nonda tau garu kami nanam. Muntu tamamo dalam wilayah kami nan de no tu terima nan apa boe serea kubir ya serusak leng nya". (We as indigenous people will permanently maintain our cultures and traditions. Before the presence of a mining company, we live restfully and peacefully. The presence of a mining company in our customary territory destroys and destruct all everything, mainly what was done to the ancient graves of our ancestors. It is incredibly unacceptable). (Interview with DS, February $4^{\mathrm{h}}$ 2019).

As narrated by DS above, before the presence of PT. Newmont Nusa Tenggara, which now has been changed into PT. Amman Mineral Nusa Tenggara (AMNT), the life and cultural identity of Berco Tribe were highly significant to retain its existence as a communal society united by a tribal similarity, laws, and customary order. This existence was demonstrated through traditional rituals which previously run smoothly. The condition was then different after the presence of PT. Newmont Nusa Tenggara. The firm conducted exploration in 2016 in the territory of the customary forest, which disturbed the sustainability of Berco Tribe's life. In line with DS, SB also accounted the similar condition about the destruction and drilling of ancestral graves of Berco Tribe, as has been explained below:

"Ba pang nongka tuberi leng kami, alo kakena bor kuber balo tolo kami nan pang ka entek emosi masyarakat nan. Ke no aku lok denan ka kuber balo tolo kami”. (The drilling activity conducted by a mining company in our ancestral graves is highly unacceptable and unforgivable. It disturbs our comfort as an heir and indigenous people). (Interview with SB, February $4^{\text {th }} 2019$ ).

The interview showed that the traditional rituals of Berco Tribe nowadays were interfered with the presence of PT. Newmont Nusa Tenggara, particularly with the drilling in the area of ancestral graves. DS also explained that the presence of the mining company would not affect traditional rituals as a form of respecting the ancestors and connecting a tie of communication (silaturrahmi) among the societies. According to DS, AZ accounted that the cultures and rituals become one of the manners to resist PT. Newmont Nusa Tenggara, as uttered below:

"Ta cara tu lawan perusaan memang ke budaya. Siong tu tolak tapi gita budaya kami ta..ritualritual adat ade kamo ada kaling jaman semuan ahe ana". (One of our ways to fight against this mining company is by using cultural and ritual approach that have been inherited to us. We, as indigenous people, do not wholly reject the company, but the company must consider us a cultural society). (Interview with AZ, February $4^{\text {th }} 2019$ ).

From the interview with AZ above, it explained that society did not reject the presence of PT. Newmont Nusa Tenggara, but this mining company must regard the situation that there is a communal society in the area of mining exploration that is still upholding the ancestors' heritage of cultures and rituals.

"Lamin sejara nomo bau mirik, kami ta tau teruna ta kaling tu boat ke tu pertahankan nan ade masi tu bau". (History cannot be deceived. We as indigenous people will always defend and preserve our cultures until forever). (Interview with SB, February $4^{\text {th, }} 2019$ ).

SB explained that the existence of indigenous people of Cek Bocek Salesek Reen Sury must be accepted as a history of the long journey of a group of humans and culture that has been preserved from generation to generation as a way of respecting the ancestors. 


\section{CONCLUSION}

An indigenous people is a group of people that lives as a tribe in independence countries which its social, cultural, and the economic condition differs from other societies, and it has settled in a particular territory in a time of conquest and colonialism in order to preserve their sovereignty (Swepston, 1990). It means that a communal society that proclaims themselves as a different entity from other societies proven by the cultural identity like rituals, languages, customary orders, laws, and beliefs becomes a dominant sector that aims to preserve, develop, and inherit to the next generation. This is strengthened by Dove (2006, p. 192), who saw this thing as a fundamental existence of society in accordance with the pattern of the culture of a social institution and the system of laws.

Emerson (1962) contended that the pattern of communication begins with the dependence relation among parties that has similar aims, ties, and ideals, which relies on the acts through the similarity of identity and the ways of doing communication. The similarity owned by the society of Berco Tribe makes them more believable, respectable, and influential than someone who does not possess a similar identity. Besides, the society of Berco Tribe believes the strength of culture, language, and customary order as a strong foundation to face conflict. Afterward, a system of Rapulung becomes the only communication that can be practiced in the context of conflict. Consequently, a process of relationship between culture and land conflict is considered as a process that involves the interaction and existence of a group.

Furthermore, a communication pattern applied by the society of Berco Tribe, Lawin Village, Sumbawa Besar, was its existence and cultural identity as a form of resistance. In the situation of conflict, Berco Tribe made the culture and tradition as the strength that influenced the choices, methods, and strategies for handling conflicts. The other finding of this research showed that the conflict between the society of Berco Tribe and some parties reduced the system of value, identity, and communication pattern, which involved some parties. The implementation of the deliberate instruction system -or so-called Rapulung-becomes a significant process that was done from generation to generation, enabling it to be a noble ritual and what made the value system retain. Besides, the cultural identity is essential as a form of resistance, which becomes a variability of the individual in influencing the choices and strategies in the conflict situation.

The researchers recommend the importance of communication science as a study that must not be separated in every social phenomenon, primarily the phenomena of land conflict. The next researchers are urged to analyze another aspect of the study of conflict communication that is in line with the development and the field situation. Furthermore, it is vital to envisage different methods because of the limitation of the researcher in order to minimize and portray the real situation.

\section{REFERENCES}

Alting, H. (2013). Konflik Penguasaan Tanah di Maluku Utara: Rakyat Versus Penguasa Dan Pengusaha. Journal of Dinamika Hukum, (13) 2, 266-282

Anindita. F. (2015). Masyarakat Adat, Penguasaan Hutan Adat dan Konsesi Pertambangan Masyarakat Adat Cek Bocek Vs Newmont Nusa Tenggara. Working Paper Sajogyo Institute. 2.

Anshori, M. S., Kriyantono, R., \& Wulandari, M. P. (2017). Negotiation Intermediaries Dan Identifikasi Penyelesaian Sengketa Hak Atas Tanah Masyarakat Adat Cek Bocek Salesek Reen Sury Di Kabupaten Sumbawa. Jurnal IUS Kajian Hukum dan Keadilan, 5(3), 481496.

Bavelas, A. (1950). Communication Patterns in Task-Oriented Groups. The Journal of The Acoustical Society Of America, 22(6), 725-730. doi: http://dx.doi.org/10.1121/1.1906679

Brown, C. T., Yelsma, P., \& Keller, P. W. (1981). Communication-Conflict Predisposition Development of A Theory And An Instrument. Human Relations, 34(12), 1103-1117.

Brørby, O. A. (2013). The Dynamics of Conflicts Within A Multicultural Organization: A Qualitative Study Of Conflicts That Arise Between Employees And Within Two Departments. Norwegian University of Sciences and Technology (NTNU) Faculty of Social Sciences and Technology Management Department of Psychology.

Denzin, N. K. (1989). Aesthetics and The Practices of Qualitative Inquiry. Qualitative Inquiry, 6(2), 
256-265. doi: 10.1177/107780040000600208.

Dove, M. R. (2006). Indigenous People and Environmental Politics. Annu. Anthropol., 35, 191-208.

Emerson, R. M. (1962). Power-Dependence Relations. American Sociological Review, 31-41.

Festinger, L. (1950). Informal Social Communication. Psychological Review, 57(5), 271.

Fisher, Aubrey B. (1986). Teori Teori Komunikasi. Bandung: CV. Remadja Karya

Finlay, L. \& Ballinger, C. (2006). Going Exploring: The Nature of Qualitative Research. Qualitative Research for Allied Health Professionals: Challenging Choices. England: Whurr Publishers Limited

Gadgil, M., Berkes, F., \& Folke, C. (1999). Indigenous Knowledge for Biodiversity Conservation. Ambio, 22 (2/3), 151-156.

Greenaway, K. H., Wright, R. G., Willingham, J., Reynolds, K. J., \& Haslam, S. A. (2015). Shared identity is key to effective communication. Personality and Social Psychology Bulletin, 41(2), 171-182.

Guba, E. G., Smith, H. J., Marshall. C. (1990). The Paradigm Dialog. California: Sage Publications

Gunawan, J. (2015). Implementasi Permendagri NO 52 Tahun 2014 Tentang Pedoman Pengakuan Dan Perlindungan Masyarakat Hukum Adat (Studi Terhadap Keberadaan Masyarakat Adat Cek Bocek Selesek Reen Suri Di Kabupaten Sumbawa). Master's Thesis, Fakultas Hukum Unram.

Hinds, P. J., \& Mortensen, M. (2005). Understanding Conflict in Geographically Distributed Teams: The Moderating Effects Of Shared Identity, Shared Context, And Spontaneous Communication. Organization Science, 16(3), 290-307.

Hirokawa, R. Y. (1980). A Comparative Analysis of Communication Patterns Within Effective Andineffective Decision-Making Groups. Communications Monographs,_47(4), 312-321. doi: $10.1080 / 03637758009376040$

Hogg, M. A., \& Reid, S. A. (2006). Social Identity, Self-Categorization, And the Communication of Group Norms. Communication Theory, 16(1), 7-30.

Jeong, A. (2005). A Guide to Analyzing Message-Response Sequences and Group Interaction Patterns In Computer-Mediated Communication. Distance Education, 26(3), 367-383.

Kendon, A. (1990). Conducting interaction: Patterns of behavior in focused encounters (Vol. 7). CUP Archive.

Kim, B. (2001). Social Constructivism: Emerging Perspectives on Learning, Teaching and Technology. M. Orey. Available online at http://projects.coe.uga.edu/epltt/index

Kriyantono, R. (2012). Teknik Praktis Riset Komunikasi: Disertai Contoh Praktis Riset Public Relations, Komunikasi Organisasi, Media Massa Dan Pemasaran. Jakarta: Prenada Media.

Kriyantono, R. (2015). Minggu keempat. Etnografi; Deskriptif \& Kritis (Powerpoint Slides) terpublikasi, Universitas Brawijaya Malang, Jawa Timur, Indonesia. Online: http://rachmatkriyantono.lecture.ub.ac.id/

Kurnia, T. (2007). The Struggle Over Land Rights: A Study of Indigenous Property Rights in Indonesia. Doctoral Dissertation, University of Washington.

Kriyantono, R. (2014). Teknik Praktis Riset Komunikasi. Jakarta: Kencana Prenadamedia Group.

Li, T. M. (2001). Masyarakat Adat, Difference, and the Limits of Recognition in Indonesia's Forest Zone. Modern Asian Studies, 35(03), 645-676.

Liliweri, A. (2005). Prasangka \& Konflik: Komunikasi Lintas Budaya Masyarakat Multikultur. Yogyakarta: PT LKiS Pelangi Aksara.

Miles, M. B., \& Huberman, A. M. (1984). Qualitative Data Analysis: A Sourcebook of New Methods. California: Sage Publication, Inc.

Mohr, J. \& Spekman, R. (1994). Characteristics of Partnership Success: Partnership Attributes, Communication Behavior, And Conflict Resolution Techniques. Strategic Management Journal, 15(2), 135-152. doi: 10.1002/smj.4250150205

Nanang, M., \& Inoue, M. (2000). Local Forest Management in Indonesia: A Contradiction Between National Forest Policy And Reality. International Review for Environmental Strategies, 1(1), 175-191.

Owens, Robert, Valesky \& Thomas. (2007). Organizational Behavior in Education. Allyn \& Bacon.

Rachman, N. F. \& Siscawati. M. (2014). Masyarakat Hukum Adat Adalah Bukan Penyandang Hak, Bukan Subjek Hukum, dan Bukan Pemilik Wilayah Adatnya. Wacana Jurnal Transformasi Sosial, 33, 3-23.

Salim, H. S., \& Abdullah, I. (2012). Penyelesaian Sengketa Tambang: Studi Kasus Sengketa Antara 
Masyarakat Samawa Dengan Pt. Newmont Nusa Tenggara. Mimbar Hukum-Fakultas Hukum Universitas Gadjah Mada, 24(3), 476-488. doi: 10.22146/jmh.407

Spears, R., \& Postmes, T. (2015). Group Identity, Social Influence, and Collective Action Online. The Handbook of the Psychology of Communication Technology, John Wiley \& Sons, Oxford, 23-46.

Spradley, J. P. (2016). Participant Observation. United State of America: Waveland Press.

Spradley, J. P. (2016). The Ethnographic Interview. United State of America: Waveland Press.

Suzuki, S. (1997). Cultural Transmission in International Organizations Impact of Interpersonal Communication Patterns in Intergroup Contexts. Human Communication Research, 24(1), 147-180. doi: 10.1111/j.1468-2958.1997.tb00590.x

Swepston, L. (1990). A New Step in the International Law on Indigenous and Tribal Peoples: ILO Convention No. 169 of 1989. Okla. City UL Rev., 15, 677.

Thorkildsen, A., \& Ekman, M. (2013). The Complexity of Becoming: Collaborative Planning and Cultural Heritage. Journal of Cultural Heritage Management and Sustainable Development, 3(2), 148-162.

Turner, J. C. (1982). Towards A Cognitive Redefinition Of the Social Group. Social Identity and Intergroup Relations, 15-40.

Woo, Y., \& Reeves, T. C. (2007). Meaningful Interaction in Web-Based Learning: A Social Constructivist Interpretation. The Internet and Higher Education, 10(1), 15-25 